\title{
Radiotherapy in Patients with Mycosis Fungoides and Central Nervous System Involvement
}

\author{
Garrett L. Jensen $^{a} \quad$ Bouthaina S. Dabaja $^{b}$ Chelsea C. Pinnix ${ }^{b}$ \\ Jillian R. Gunther ${ }^{b}$ Auris Huen ${ }^{c}$ Madeleine Duvic ${ }^{c}$ Yasuhiro Oki ${ }^{d}$ \\ Michelle Fanale $^{d} \quad$ Chitra Hosing ${ }^{\mathrm{e}}$ Sarah A. Milgrom ${ }^{\mathrm{b}}$ \\ aDepartment of Radiation Oncology, Baylor Scott and White, Temple, TX, USA; \\ ${ }^{b}$ Department of Radiation Oncology, The University of Texas MD Anderson Cancer Center, \\ Houston, TX, USA; 'Department of Dermatology, The University of Texas MD Anderson \\ Cancer Center, Houston, TX, USA; dDepartment of Lymphoma/Myeloma, The University of

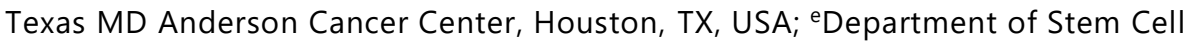 \\ Transplantation and Cellular Therapy, The University of Texas MD Anderson Cancer \\ Center, Houston, TX, USA
}

\section{Keywords}

Mycosis fungoides $\cdot$ Sezary syndrome $\cdot$ Cutaneous lymphoma $\cdot$ CNS, Brain

\begin{abstract}
Background: Involvement of the central nervous system (CNS) by mycosis fungoides (MF) is rare; however, it portends a poor prognosis. While aggressive multimodality therapy may improve outcomes, the role of radiation therapy (RT) is not well defined. Objectives: We sought to explore the efficacy of RT in the management of CNS involvement by MF. Method: We retrospectively identified five patients with MF and CNS involvement who received cranial or craniospinal RT at a single institution. Patient characteristics, disease features, radiographic findings, treatments delivered, and outcome data were extracted from the electronic medical record. Results: All 5 patients had neurologic deficits at RT initiation, and 4 experienced at
\end{abstract}

The University of Texas MD Anderson Cancer Center 77030 


\section{Case Reports in Oncology}

Case Rep Oncol 2018;11:721-728

DOI: $10.1159 / 000494081$

(c)

2018 The Author(s). Published by S. Karger AG, Base www.karger.com/cro

Jensen et al.: Radiotherapy in Patients with Mycosis Fungoides and Central Nervous System Involvement

least a partial improvement. Of 4 patients evaluated by MRI after RT completion, 3 had complete resolution of CNS disease within the irradiated field. At the time of last follow-up, all patients had died of MF. The median time to death was 7.4 months (range 1.0-21 months) from their diagnosis with CNS involvement and 1.2 months (range 0.4-7.1 months) from the end of RT treatment. Conclusions: We observed high rates of radiographic response and palliation of neurological symptoms. Nonetheless, all patients succumbed to their disease shortly after treatment, confirming the poor prognosis of this condition. Our findings suggest that RT may play a valuable palliative role for these patients.

(C) 2018 The Author(s)

Published by S. Karger AG, Basel

\section{Introduction}

Mycosis fungoides (MF) and Sezary Syndrome are the most common forms of cutaneous T-cell lymphoma [1]. The disease can progress to involve extracutaneous sites, most commonly the lymph nodes, spleen, lungs, liver, bone, and kidney [2]. Central nervous system (CNS) involvement by MF is rare. In one series of 680 newly diagnosed cases of MF, $1.3 \%$ were found to have CNS involvement during follow-up [3]. In another series of 187 patients with MF, three patients (1.6\%) experienced CNS involvement [4]. Although clinically apparent CNS involvement is uncommon, the rates of subclinical involvement may be higher. For example, in deceased patients with MF who underwent an autopsy, CNS involvement was observed in $11-14 \%$ of cases $[2,5,6]$. with the meninges more commonly involved than the brain parenchyma [7].

Outcomes are generally poor for patients with MF involving the CNS, with reported survival times in the range of 3-6 months [8-10]. Aggressive multimodality therapy may improve the prognosis; however, the role of radiation therapy (RT) is not well defined. We aimed to assess the efficacy of RT in the management of MF involving the CNS. Our primary outcomes were local disease control and palliation of neurologic symptoms. Secondarily, we evaluated survival times after the identification of CNS disease and after the completion of RT.

\section{Case Series}

After IRB approval was obtained, we identified all patients with CNS involvement by MF who were treated with cranial or craniospinal RT at a single institution from 2006 to 2016. Patient characteristics, disease features, radiographic findings, treatments delivered, and outcome data were extracted from the electronic medical record.

\section{Results}

Patient and Disease Characteristics

Five patients were identified who had CNS involvement by MF and were treated with cranial or craniospinal RT. Their characteristics at initial diagnosis through identification of CNS disease, and at the initiation of RT are presented in Table 1 and Table 2. The median age at the 
time of initial biopsy-proven MF was 65 years (34-69 years). Staging at the time of initial diagnosis with MF was IA (1 patient), IB ( 2 patients), IIB (1 patient), and IVB (1 patient). Before the identification of intracranial disease, 2 patients developed Sezary Syndrome and 4 developed visceral disease involvement. Large cell transformation (LCT) was confirmed in 4 patients at a median time from diagnosis of 3 years (range $0-21$ years).

The median time from the initial MF diagnosis to the identification of CNS involvement was 1.4 years (range 1-21 years). In the patient with a prolonged interval of 21 years between the initial MF diagnosis and the identification of CNS disease, LCT occurred soon before intracranial involvement was diagnosed. Neurologic deficits were present in 4 patients when intracranial involvement was identified. The final patient was asymptomatic, with epidural disease in the thoracic spine discovered incidentally on imaging and malignant cells identified in the cerebrospinal fluid (CSF) on a confirmatory lumbar puncture. At the time of diagnosis with CNS involvement, all 5 patients had radiographic evidence of disease. CSF was assessed in 4 patients and contained malignant cells in 2 patients. A biopsy confirmed CNS involvement in 3 patients. When CNS disease was identified, all patients had active cutaneous disease (T1 in 3 patients, T2 in 2 patients). In addition, 4 of 5 patients had extra-cranial, non-cutaneous metastases.

\section{Radiation Therapy Information}

Patients received RT at a median of 6.2 months (range 0.5-13 months) after the identification of CNS disease. At the initiation of RT, all 5 patients had radiographic evidence of CNS disease and had neurologic deficits. For 2 patients (cases 1 and 5), RT was the first therapy given after the identification of CNS disease. Three patients (cases 2, 3, and 4) received CNSdirected chemotherapy after the identification of intracranial disease and prior to RT; all 3 of these patients experienced CNS disease progression while on chemotherapy, so salvage RT was recommended.

RT targeted the whole brain (WBRT) to a median total dose of 28 Gy (range 20-30.6 Gy) at a median of $2 \mathrm{~Gy} /$ fraction (range 1.6-2). In addition, one patient received a boost to the gross disease of an additional $11 \mathrm{~Gy}$ (total dose to gross disease $36 \mathrm{~Gy}$ ). Three patients were treated to the spine, in addition to the brain, with comprehensive craniospinal irradiation (CSI). In one patient treated with CSI (case 1), the inferior brain, skull base, and cervical spine were excluded from the treatment volume to respect normal tissue tolerance, because this patient had received RT to the scalp, oral cavity and oropharynx previously.

\section{Response to Radiation Therapy}

After completion of RT, 4 patients were evaluated by MRI (cases 1-4). In 2 patients (cases 2-3), the MRI revealed complete resolution of all evidence of CNS disease. In 1 patient (case 4), MRI revealed no evidence of disease in the brain and a significant reduction in spinal epidural disease; however, persistent mild enhancement of the cauda equina was appreciated, so residual leptomeningeal disease could not be excluded. In the final patient (case 1), an MRI showed no evidence of disease within the irradiated area; however, CNS disease progressed within the unirradiated gap between the cranial and spinal fields.

All 5 patients had neurologic deficits at the initiation of RT. Of these, 4 experienced at least a partial improvement in these symptoms. One patient (case 4) had a partial radiographic response to CSI without any corresponding symptomatic improvement. Four of the 5 patients 
with extremity weakness or impaired gait had improvement after RT. All patients with blurry vision (case 2 and 5) and cranial nerve palsy (case 2) experienced symptomatic relief.

The therapies given after RT are summarized in Table 2. Three patients received additional CNS-directed chemotherapy. Additionally, one patient underwent allogeneic stem cell transplantation with fludarabine and melphalan conditioning.

Two patients experienced CNS disease progression after the completion of RT. As described above, case 1 experienced disease progression within the unirradiated gap in the modified CSI plan. Progression was identified 14 days after completion of modified CSI, when the patient presented with a facial nerve palsy. In addition, case 3 achieved a complete response to WBRT, and then was treated with total skin electron beam therapy and allogeneic stem cell transplantation with fludarabine and melphalan. Subsequently, his disease progressed in the brain, skin, and muscle. Relapse within the brain was first appreciated 4 months after the completion of RT in a region that had received $30.6 \mathrm{~Gy}$.

At the time of last follow-up, all patients had died of MF. The median time to death was 7.4 months (range 1.0-21 months) from their diagnosis with CNS involvement and 1.2 months (range 0.4-7.1 months) from the end of RT.

\section{Discussion/Conclusion}

In this series of 5 patients with MF and CNS involvement, we identified high rates of radiographic and clinical disease response to RT. All patients who were evaluated by MRI after the completion of RT achieved at least a partial response in the irradiated area. Furthermore, 4 of the 5 patients with neurologic deficits at the initiation of RT achieved at least a partial improvement in their symptoms. These findings demonstrate an important role of RT to provide local control and palliation of neurologic deficits. The high response rates are consistent with the known radiosensitivity of primary cutaneous lymphoma [11]. Three patients in this cohort experienced CNS disease progression while receiving CNS-directed chemotherapy, prior to treatment with salvage RT; their disease responded to RT, suggesting that CNS MF remains responsive to $\mathrm{RT}$, even if it has been refractory to other CNS-directed therapy.

Despite these high rates of CNS disease response to RT, OS times were short, confirming the poor prognosis of this condition. From the time of identification of CNS disease, the median survival was 7.4 months (range 1.0-21 months); from the time of completion of cranial RT, the median survival was only 1.2 months (range 0.4-7.1 months). These findings are consistent with previously published outcomes of patients with MF involving the CNS, with median survival periods of just six months $[6,9,12-14]$ and only three months in patients treated with RT alone [3, 5-7, 14]. Nonetheless, prolonged OS is possible. Patients in the literature with the longest reported survival times received aggressive CNS-directed therapy and had limited systemic involvement $[8,9,13,15]$. Bird et al. demonstrated particularly good survival outcomes of 10,10, 23, and 33 months using temozolamide +/- MTX, with low-dose WBRT. The long-term survivors in that study had no other visceral disease involvement, suggesting that CNS-directed therapy can result in long-term survival in patients with limited extracranial disease [15]. Consistent with these findings, 2 patients in our series experienced survival times $>15$ months after the identification of CNS disease. These two patients received 
aggressive multi-modality therapy and had systemic involvement that was limited to bone and/or muscle.

Multiple features of our patients are consistent with other cases in the literature. For example, all patients developed neurologic deficits from their CNS disease, 4 of 5 had visceral organ involvement, and 4 of 5 experienced LCT. Likewise, other researchers have shown that CNS involvement by MF may be associated with severe neurologic deficits and is more common in patients with visceral organ involvement or LCT [3, 6, 7]. In one study, the risk of CNS involvement was associated with T3-4, N3, B1, or M1 stage disease at initial diagnosis. The presence of at least two of these four factors indicated a 15.6\% 10-year risk rate of developing CNS involvement. This risk rose to $36 \%$ when other (i.e. non-CNS) visceral sites were involved during the clinical course of the disease [3].

Several patients in this series had unique presentations. Patient 3 had a prolonged time of 21 years between his initial diagnosis with MF and the development of CNS disease, which occurred shortly after LCT was identified. In other reports, CNS disease has been identified earlier, typically within 5 years of the upfront MF diagnosis [5, 8]. Patient 2, who did not have LCT, was asymptomatic at presentation. It is rare for CNS involvement to be an incidental radiographic finding, since it is not screened for in MF. Typically, patients present with neurologic symptoms, such as confusion, nausea, headaches, gait difficulties, lethargy and weak ness [9].

We conclude that RT is a valuable tool for providing palliation of neurologic symptoms due to CNS involvement in this population. In the setting of extensive CNS disease and/or limited systemic burden, we advocate for comprehensive irradiation of the neuroaxis (i.e. CSI), with the aim of providing durable CNS disease control. However, in the setting of significant extra-cranial disease, survival times are short, so irradiation of a more limited field (ex. WBRT) may be appropriate. Our findings confirm the poor prognosis of MF that has spread to the CNS and suggest the need for aggressive local and systemic therapy, which may extend survival, especially in the setting of limited visceral disease.

\section{Acknowledgement}

None.

\section{Statement of Ethics}

The authors have no ethical conflicts to disclose.

\section{Disclosure Statement}

The authors have no conflicts of interest to declare. 


\section{Funding Sources}

This research did not receive any specific grant from funding agencies in the public, commercial, or not-for-profit sectors.

\section{Author Contributions}

G.L.J. and S.A.M. collected the clinical data and wrote the manuscript. All authors contributed to the study concept and reviewed the final manuscript.

\section{References}

1 Foss FM, Girardi M. Mycosis Fungoides and Sezary Syndrome. Hematol Oncol Clin North Am. 2017 Apr;31(2):297-315.

2 Epstein EH Jr, Levin DL, Croft JD Jr, Lutzner MA. Mycosis fungoides. Survival, prognostic features, response to therapy, and autopsy findings. Medicine (Baltimore). 1972 Jan;51(1):61-72.

3 Stein M, Farrar N, Jones GW, Wilson LD, Fox L, Wong RK, et al. Central neurologic involvement in mycosis fungoides: ten cases, actuarial risk assessment, and predictive factors. Cancer J. 2006 Jan-Feb;12(1):55-62.

4 Kaufman DK, Habermann TM, Kurtin PJ, O'Neill BP. Neurological complications of peripheral and cutaneous T-cell lymphomas. Ann Neurol. 1994 Oct;36(4):625-9.

5 Hallahan D, Griem M, Griem S, Duda E, Baron J. Mycosis fungoides involving the central nervous system. J Clin Oncol. 1986 Nov;4(11):1638-44.

6 Tien RD, Brown M, Massey EW. CNS mycosis fungoides: CT and MR findings. J Comput Assist Tomogr. 1992 Jul-Aug;16(4):529-33.

7 Zonenshayn M, Sharma S, Hymes K, Knopp EA, Golfinos JG, Zagzag D. Mycosis fungoides metastasizing to the brain parenchyma: case report. Neurosurgery. 1998 Apr;42(4):933-7.

8 Li N, Kim JH, Glusac EJ. Brainstem involvement by mycosis fungoides in a patient with large-cell transformation: a case report and review of literature. J Cutan Pathol. 2003 May;30(5):326-31.

9 Vu BA, Duvic M. Central nervous system involvement in patients with mycosis fungoides and cutaneous large-cell transformation. J Am Acad Dermatol. 2008 Aug;59(2 Suppl 1):S16-22.

10 Lally A, Hollowood K, Whittaker S, Turner R. Central nervous system involvement in stage 1b mycosis fungoides. Br J Dermatol. 2007 Oct;157(4):815-6.

11 Cotter GW, Baglan RJ, Wasserman TH, Mill W. Palliative radiation treatment of cutaneous mycosis fungoides—a dose response. Int J Radiat Oncol Biol Phys. 1983 Oct;9(10):1477-80.

12 Beylot-Barry M, Dubus P, Vergier B, Cogrel O, Marit G, Beylot C, et al. Meningeal involvement by a transformed mycosis fungoides following Hodgkin's disease. Br J Dermatol. 1999 Nov;141(5):909-13.

13 Bodensteiner DC, Skikne B. Central nervous system involvement in mycosis fungoides: diagnosis, treatment and literature review. Cancer. 1982 Sep;50(6):1181-4.

14 Grevelink SA, Fuller GN, Olsen EA. Central nervous system involvement by cutaneous T cell lymphoma. J Am Acad Dermatol. 1991 Sep;25(3):542-9.

15 Bird TG, Whittaker S, Wain EM, Child F, Morris SL. Temozolomide for central nervous system involvement in mycosis fungoides. Int J Dermatol. 2016 Jul;55(7):751-6. 


\section{Case Reports in Oncology}

\begin{tabular}{l|l}
\hline Case Rep Oncol 2018;11:721-728 \\
\hline DOI: 10.1159/000494081 & $\begin{array}{l}\text { (c) 2018 The Author(s). Published by S. Karger AG, Basel } \\
\text { www.karger.com/cro }\end{array}$ \\
\hline
\end{tabular}

Jensen et al.: Radiotherapy in Patients with Mycosis Fungoides and Central Nervous System Involvement

Table 1. Patient characteristics at MF diagnosis until identification of CNS disease

\begin{tabular}{|c|c|c|c|c|c|c|c|c|c|c|c|c|c|c|}
\hline $\begin{array}{l}\text { Case, } \\
n\end{array}$ & $\begin{array}{l}\text { Age, } \\
\text { gender } \\
\text { at initial } \\
\text { Dx, } \\
\text { years }\end{array}$ & $\begin{array}{l}\text { Stage } \\
\text { at } \\
\text { initial } \\
\text { Dx }\end{array}$ & $\begin{array}{l}\text { Worst } \\
\text { stage } \\
\text { prior to } \\
\text { CNS } \\
\text { involve- } \\
\text { ment }\end{array}$ & $\begin{array}{l}\text { Time from } \\
\text { initial } \\
\text { Dx to } \\
\text { CNS } \\
\text { disease, } \\
\text { years }\end{array}$ & $\begin{array}{l}\text { Time from } \\
\text { initial Dx } \\
\text { to LCT, } \\
\text { years }\end{array}$ & $\begin{array}{l}\text { Ever } \\
\text { CD30+ }\end{array}$ & $\begin{array}{l}\text { Therapies prior to } \\
\text { CNS involvement, } \\
\text { non-RT }\end{array}$ & $\begin{array}{l}\text { RT prior to } \\
\text { cranial RT }\end{array}$ & $\begin{array}{l}\text { Neurologic } \\
\text { symptoms }\end{array}$ & $\begin{array}{l}\text { Radiographic } \\
\text { evidence of } \\
\text { disease } \\
\text { (parenchymal, } \\
\text { LMD, cord } \\
\text { involvement) }\end{array}$ & CSF & Biopsy & $\begin{array}{l}\text { Other sites } \\
\text { of non- } \\
\text { cutaneous, } \\
\text { extra-cranial } \\
\text { disease at } \\
\text { CNS Dx }\end{array}$ & $\begin{array}{l}\text { Skin } \\
\text { involvement, } \\
\text { BSA (weeks } \\
\text { prior to CNS } \\
\text { involvement) }\end{array}$ \\
\hline 1 & $65, \mathrm{M}$ & IVB & IVB & 1.4 & 1.2 & $\mathrm{~N}$ & $\begin{array}{l}\text { Phototherapy, } \\
\text { interferon alfa- } 2 \mathrm{~b} \text {, } \\
\text { topical/systemic } \\
\text { steroids, gemcitabine, } \\
\text { doxorubicin, } \\
\text { bexarotene }\end{array}$ & $\begin{array}{l}\text { Local RT to } \\
\text { skin, nodes, } \\
\text { oropharynx, } \\
\text { and right orbit }\end{array}$ & $\begin{array}{l}\text { LE } \\
\text { weakness }\end{array}$ & $\begin{array}{l}\text { Leptomeningeal } \\
\text { disease of the } \\
\text { cauda equina }\end{array}$ & + & $\mathrm{Y}$ & $\begin{array}{l}\text { LN, ST, } \\
\text { head and } \\
\text { neck, }\end{array}$ & $50 \%(-3)$ \\
\hline 2 & $66, \mathrm{M}$ & IIB & IVB & 0.7 & N/A & $\mathrm{N}$ & Plaquenil, dapsone & $\begin{array}{l}\text { Local RT to } \\
\text { right eye and } \\
\text { orbit }\end{array}$ & None & $\begin{array}{l}\text { Epidural disease } \\
\text { of thoracic spine }\end{array}$ & + & $\mathrm{N}$ & $\begin{array}{l}\text { Muscle, } \\
\text { bone, ST }\end{array}$ & $6 \%(-3)$ \\
\hline 3 & 46, M & IB & IIB & 20.7 & 20.5 & $\mathrm{Y}$ & $\begin{array}{l}\text { Topical steroids, } \\
\text { nitrogen mustard, } \\
\text { bexarotene, } \\
\text { phototherapy, } \\
\text { acitretin }\end{array}$ & $\begin{array}{l}\text { Local RT to } \\
\text { skin }\end{array}$ & $\begin{array}{l}\text { Ataxia, } \\
\text { aphasia }\end{array}$ & $\begin{array}{l}\text { Brain } \\
\text { parenchymal } \\
\text { disease }\end{array}$ & - & $\mathrm{Y}$ & bone & $0.1(0)$ \\
\hline 4 & $69, \mathrm{M}$ & IA & IVB & 3.9 & 4.9 & $\mathrm{Y}$ & $\begin{array}{l}\text { Topical/systemic } \\
\text { steroids, phototherapy, } \\
\text { bexarotene, interferon, } \\
\text { forodesine, } \\
\text { zanolimumab, } \\
\text { nitrogen mustard, } \\
\text { vorinostat }\end{array}$ & $\begin{array}{l}\text { TSEB, Lum- } \\
\text { bosacral } \\
\text { spine }\end{array}$ & $\begin{array}{l}\text { LE } \\
\text { weakness }\end{array}$ & $\begin{array}{l}\text { Epidural } \\
\text { disease, brain } \\
\text { parenchymal } \\
\text { involvement }\end{array}$ & Unk & $\mathrm{Y}$ & $\begin{array}{l}\text { Bone, } \\
\text { muscle }\end{array}$ & $13(1.4)$ \\
\hline 5 & $34, \mathrm{~F}$ & IB & IVA & 1.2 & 0.1 & $\mathrm{Y}$ & $\begin{array}{l}\text { Topical steroids, photo- } \\
\text { therapy, } \\
\text { interferon alfa- } 2 \mathrm{~b} \text {, } \\
\text { hyper-CVAD }\end{array}$ & - & $\begin{array}{l}\text { CN VII } \\
\text { palsy, LE } \\
\text { weakness }\end{array}$ & $\begin{array}{l}\text { Sacral nerve } \\
\text { root and brain } \\
\text { parenchymal } \\
\text { disease }\end{array}$ & - & $\mathrm{N}$ & LN & $<0.01(0)$ \\
\hline
\end{tabular}

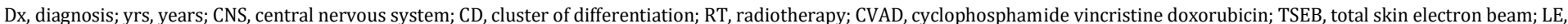
lower extremity; CN, cranial nerve; Unk, unknown; LN, lymph nodes; ST, soft tissue; BSA, body surface area. 
Jensen et al.: Radiotherapy in Patients with Mycosis Fungoides and Central Nervous

System Involvement

Table 2. CNS RT, response, and outcome

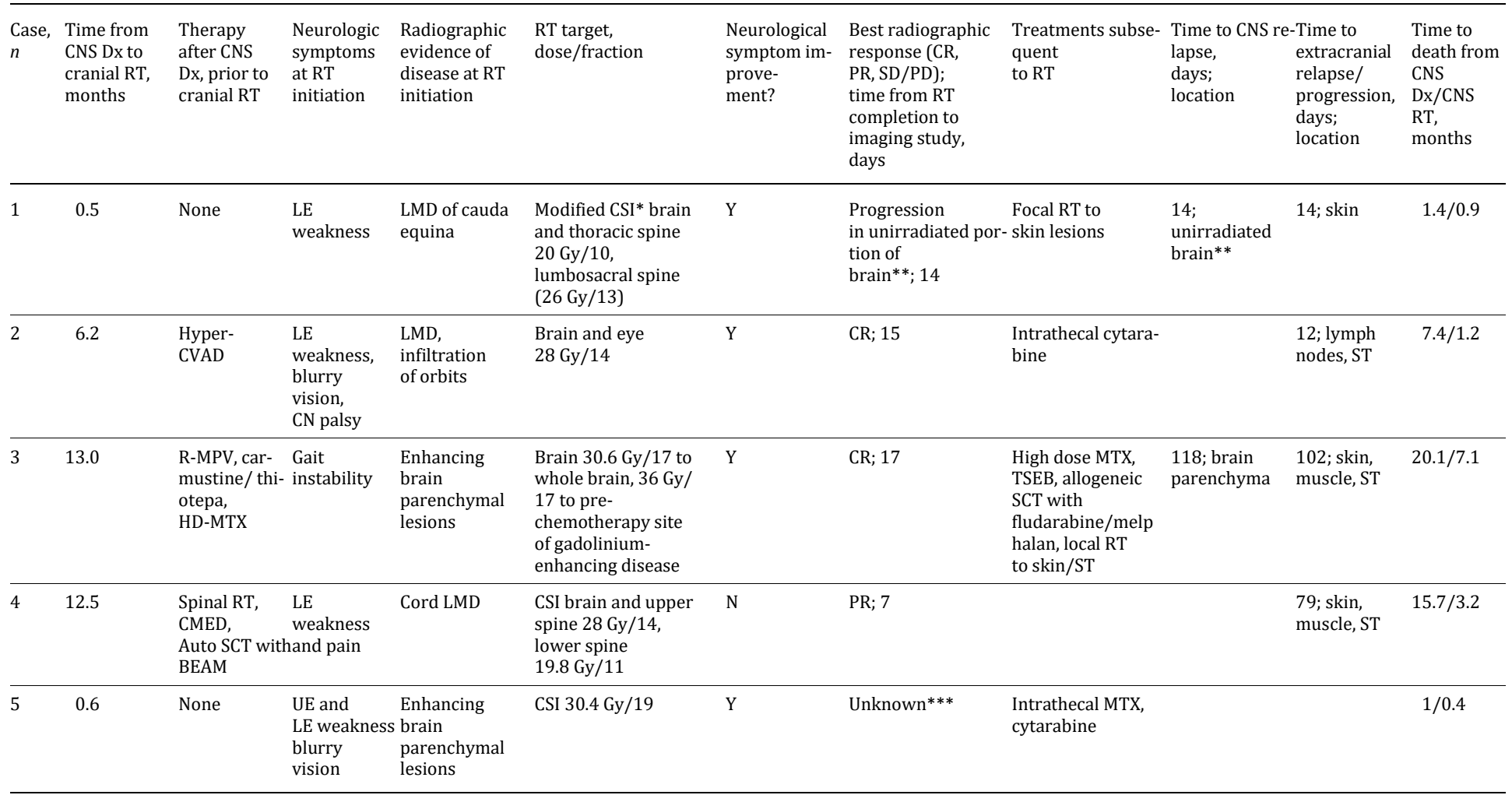

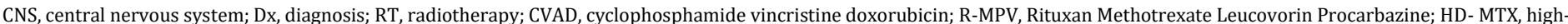

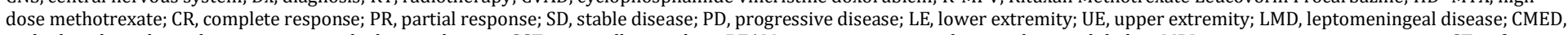

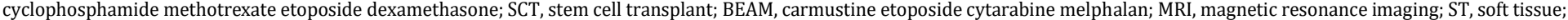

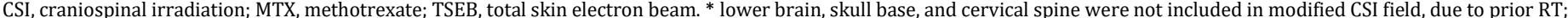
** disease progressed within the gap in the modified CSI plan; *** no imaging was performed after radiotherapy. 